\title{
Lebectin, a novel C-type lectin from Macrovipera lebetina venom, inhibits integrin- mediated adhesion, migration and invasion of human tumour cells
}

Sameh Sarray ${ }^{1,5}$, Virginie Berthet ${ }^{2}$, Juan J Calvete ${ }^{3}$, Jeannine Secchi ${ }^{2}$, Jacques Marvaldi ${ }^{2}$, Mohamed El Ayeb ${ }^{1}$, Naziha Marrakchi ${ }^{1,4}$ and José Luis ${ }^{2}$

${ }^{1}$ Laboratoire des venins et toxines, Institut Pasteur de Tunis, Tunis, Tunisie; ${ }^{2}$ CNRS UMR6032, Faculté de Pharmacie, Marseille, France; ${ }^{3}$ Instituto de Biomedicina, CSIC, Valencia, España; ${ }^{4}$ Faculté de Médecine de Tunis, Tunis, Tunisie; and ${ }^{5}$ Faculté des Sciences de Tunis, Tunis, Tunisie

\begin{abstract}
The adhesion receptors of the integrin family play an essential role during tumour progression and thus represent interesting potential targets for the development of new therapeutic agents. The snake venom contains natural inhibitors of integrin-ligand interactions called disintegrins. It also contains C-type lectin proteins mainly known as modulators of platelet aggregation. In this study, we demonstrate that lebectin, a novel C-type lectin isolated from Macrovipera lebetina venom, displayed an anti-integrin activity. Lebectin inhibited the integrin-mediated attachment of various tumour cell lines to different adhesion substrata. The Ctype lectin also completely blocked cell migration towards fibronectin in haptotaxis assays and prevented invasion of fibrin gels by tumour cells. In addition, lebectin proved to be a potent inhibitor of tumour cell proliferation. Although the specific integrins affected by lebectin are not identified in this study, the integrin $\alpha 5 \beta 1$ might be involved.
\end{abstract}

Laboratory Investigation (2004) 84, 573-581, advance online publication, 29 March 2004; doi:10.1038/labinvest.3700088

Keywords: snake venom; integrin; tumour cell adhesion; cell migration; cell proliferation; invasion; haptotaxis

The acquisition of cell motility and the capacity to invade basement membranes and adjacent tissues plays a central role in the complex multistep process of metastasis. Cell migration results in dynamic interactions between the cell, the extracellular matrix (ECM) and the cytoskeleton. These interactions are partly mediated by integrins, a family of cell surface adhesion receptors composed by the noncovalent association of $\alpha$ and $\beta$ subunits. ${ }^{1}$ Integrins connect the ECM proteins outside to the actin cytoskeleton within the cell, allowing the traction required for cell migration. $^{2,3}$ In addition to regulating cell adhesion, integrins relay molecular cues regarding the cellular environment that influence cell shape, survival, proliferation and gene transcription. Integrins therefore play a pivotal role during tumour progres-

Correspondence: José Luis, CNRS UMR6032, Faculté de Pharmacie, 27 Bd J. Moulin, 13385 Marseille Cedex 5, France.

E-mail: jose.luis@pharmacie.univ-mrs.fr

Received 3 November 2003; revised 2 February 2004; accepted 3

February 2004; published online 29 March 2004 sion (for reviews, see [Parise et $a l^{4}$ and Hood and Cheresh $\left.\left.{ }^{5}\right]\right)$.

C-type lectin proteins (CLPs) are a family of snake venom proteins that are structurally homologous to the carbohydrate recognition domain of animal C-type lectins. CLPs are $30 \mathrm{kDa}$ proteins consisting of the association of two subunits. In spite of their highly conserved primary structure (40-70\% similarity), CLPs are characterized by very distinct biological activities (see Marcinikiewicz, Wang et $a l^{7}$ and references therein). For example, several CLPs inhibit von Willebrand factor (vWF) binding to the GPIb/IX complex, thus impeding platelet agglutination, whereas alboaggregins activate the GPIb complex, causing platelet agglutination. Other CLPs exhibit anticoagulant activities by binding to $\mathrm{vWF}$ or to the coagulation factors IX and/or $\mathrm{X}$, while convulxin induces platelet aggregation by activating the collagen receptor GPVI (for a review, see Andrews and Berndt ${ }^{8}$.

Besides the action on platelet aggregation, it has recently been reported that venom CLPs, such as EMS16 from Echis multisquamatus, ${ }^{6}$ or bilinexin 
from Agkistrodon bilineatus ${ }^{9}$ have an anti- $\alpha 2 \beta 1$ integrin activity. In the case of aggretin from Calloselasma rhodostoma, recent studies gave rise to conflicting results concerning its interaction with $\alpha 2 \beta 1$ integrin. ${ }^{10-14}$ However, the targeting of CLPs might not be restricted to the $\alpha 2 \beta 1$ integrin, as we recently showed that lebecetin, isolated from Macrovipera lebetina venom, inhibits platelet aggregation $^{15}$ and adhesion of tumour cells to various ECM ligands. ${ }^{16}$

In this work, we report a novel CLP, termed lebectin, also from M. lebetina venom that inhibits various integrin-mediated functions in tumour cells, including adhesion, proliferation and cell migration.

\section{Materials and methods}

\section{Reagents}

Venom was collected from $M$. lebetina snake in the serpentarium of Institut Pasteur, Tunis. Fast protein liquid chromatography (FPLC) column and Sephadex G75 were purchased from Amersham-Pharmacia and high-performance liquid chromatography (HPLC) column was obtained from Beckman. Dulbecco's modified Eagle's medium (DMEM) was purchased from GIBCO (Cergy-Pontoise, France) and foetal calf serum (FCS) from BioWhittaker (Fontenay-sous-Bois, France). Human fibrinogen, human laminin and poly-L-lysine were from Sigma (St Louis, MO, USA). Rat type I collagen was from Upstate (Lake Placid, NY, USA) and human fibronectin from Chemicon (Temecula, CA, USA). Human vitronectin was purified according to Yatogho et al. ${ }^{17}$ The 5-bromo-2'-deoxyuridine (BrdU) kit was from Boehringer (Mannheim, Germany).

\section{Purification and N-terminal Amino-Acid Sequence of Lebectin}

M. lebetina crude venom ( $267 \mathrm{mg})$ was dissolved in $0.2 \mathrm{M}$ ammonium acetate, $\mathrm{pH} 6.8$ and fractionated by a Sephadex G75 column equilibrated with the same buffer. The fractions from peak II were loaded onto a MonoS HR5/5 column pre-equilibrated with $50 \mathrm{mM}$ HEPES $\mathrm{pH}$ 7.5. Elution was performed with a linear gradient of $0-1 \mathrm{M} \mathrm{NaCl}$. Finally, resulting fractions were purified by reverse-phase HPLC on a C8 column $(5 \mu \mathrm{m} ; 4.6 \times 250 \mathrm{~mm})$ equilibrated with $0.1 \%$ trifluoroacetic acid in $10 \%$ acetonitrile and then eluted at a flow rate of $1 \mathrm{ml} / \mathrm{min}$ with an acetonitrile linear gradient $10-80 \%$ over $60 \mathrm{~min}$.

The homogeneity and apparent molecular mass of the purified lebectin and its subunits were determined by SDS-PAGE in $12.5 \%$ acrylamide gel under reducing or nonreducing conditions and confirmed by mass spectrometry analysis as previously described. ${ }^{15}$ The protein concentration was deter- mined by the BCA protein assay (Pierce, Rochford, IL, USA).

The N-terminal amino-acid sequence of isolated native lebectin was determined as already described by using an Applied Biosystems 477A instrument. Sequence alignment was made by CLUSTAL X program.

\section{Cell Adhesion Assay}

The human fibrosarcoma (HT1080), melanoma (IGR39) and adenocarcinoma (HT29-D4) cell lines were routinely cultured in DMEM containing 10\% FCS. Human leukaemia cells K562 were cultured in RPMI medium with $10 \%$ FCS.

Adhesion assays were performed as previously described. ${ }^{18,19}$ Briefly, cells in single cell suspension were added to wells coated with purified ECM proteins and allowed to adhere to the substrata for $1 \mathrm{~h}$ (HT1080 and IGR39 cells) or $2 \mathrm{~h}$ (HT29-D4 and $\mathrm{K} 562$ cells) at $37^{\circ} \mathrm{C}$. After washing, attached cells were stained by $0.1 \%$ crystal violet and lysed with $1 \%$ SDS. Absorbance was then measured at $600 \mathrm{~nm}$. To test the dependency on divalent cations, adhesion was performed in $\mathrm{Ca}^{2+}$ - and $\mathrm{Mg}^{2+}$-free Hanks' solution $/ 0.2 \%$ borine serum albumin (BSA) (supplemented or not with $1 \mathrm{mM} \mathrm{CaCl}$ and $1 \mathrm{mM} \mathrm{MgCl}_{2}$ ) instead of adhesion buffer.

\section{Cell Migration and Invasion Assays}

In vitro cell migration assays were performed using modified Boyden chambers (NeuroProbe Inc, Bethesda, MD, USA) as previously described, ${ }^{18}$ except that incubation medium was DMEM/10\% FCS. Cells were stained with $0.1 \%$ crystal violet and migration was quantified by measure of absorbance at $600 \mathrm{~nm}$.

Tumour cell invasion of fibrin gels was carried out as described by Naito et al, ${ }^{20}$ except type I collagen $(0.67 \mathrm{mg} / \mathrm{ml})$ and lebectin $(2-10 \mu \mathrm{g} / \mathrm{ml})$ were incorporated to fibrinogen prior adding thrombin.

\section{Cell Proliferation}

IGR39, HT1080 and K562 cells were seeded at 15000 cells/cm2 in the presence or absence of $10 \mu \mathrm{g} / \mathrm{ml}$ lebectin. Every day, IGR39 and HT1080 cells were quantified by crystal violet staining as for adhesion assay. K562 cells were enumerated by manual counting of an aliquot.

Proliferation was confirmed by BrdU incorporation into DNA of cells treated for $18 \mathrm{~h}$ at $37^{\circ} \mathrm{C}$ with $10 \mu \mathrm{g} / \mathrm{ml}$ lebectin. Nuclei of proliferating cells are stained by alkaline phosphatase activity using the detection kit according to the manufacturer's instructions. Images of cells were captured and analysed using a Leica DM IRBE microscope with 
cool Snap FX camera and the Metaview software (Princeton Instrument, Paris, France).

\section{Results}

\section{Effect of Snake Venom on Tumour Cells Adhesion}

To screen for venom peptides able to inhibit tumour cells integrins, we performed cell adhesion assays using a large array of purified ECM proteins. As illustrated in Figure 1a, attachment of the melanoma cell line IGR39 to fibrinogen, fibronectin and laminin-1 was completely abolished by venom from M. lebetina, while no effect could be observed on type I collagen. This is not restricted to melanoma cells, as adhesion of human tumour cells from ovarian (IGROV1) and colonic (HT29-D4) carcinomas was also affected (data not shown). The inhibition of attachment to fibrinogen of IGR39 (Figure 1b) and IGROV1 cells (not shown)
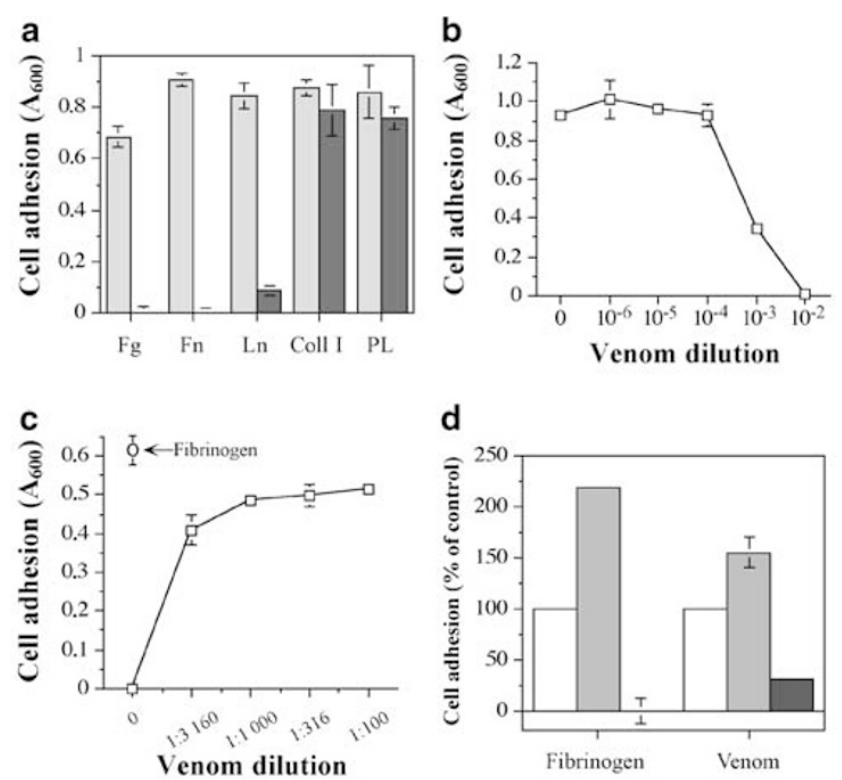

Figure 1 Effect of $M$. lebetina venom on tumour cells adhesion. (a) IGR39 cells in single cell suspension were incubated with ( or without $(\square$ ) venom from $M$. lebetina (1:100) for $30 \mathrm{~min}$ at room temperature. Cells were then added to 96-well microtiter plates coated with $10 \mu \mathrm{g} / \mathrm{ml}$ fibrinogen (Fg), fibronectin (Fn), type I collagen (Coll I) or poly-L-lysine (PL) or with $2 \mu \mathrm{g} / \mathrm{ml}$ laminin (Ln) and allowed to adhere for $1 \mathrm{~h}$ at $37^{\circ} \mathrm{C}$. After washing, adherent cells were stained with crystal violet, solubilized by SDS and absorbance was measured at $600 \mathrm{~nm}$. (b) Attachment of IGR39 cells, treated with $M$. lebetina venom at the indicated dilutions, was measured as above using wells coated with $10 \mu \mathrm{g} / \mathrm{ml}$ fibrinogen. (c) Microtiter plates were coated with $M$. lebetina venom at the indicated dilutions or with $10 \mu \mathrm{g} / \mathrm{ml}$ fibrinogen prior performing cell adhesion assays as described above. (d) IGR39 cells were resuspended, either in Hanks' solution/0.2\% BSA in the absence $(\square)$ or in the presence of $1 \mathrm{mM} \mathrm{MnCl}_{2}(\square)$, or in $\mathrm{Ca}^{2+}$. and $\mathrm{Mg}^{2+}$-free Hanks' solution/0.2\% BSA ( $\square$. Cells were then added to plates coated with $10 \mu \mathrm{g} / \mathrm{ml}$ fibrinogen or with $M$. lebetina venom (1:100) and allowed to adhere for $1 \mathrm{~h}$ at $37^{\circ} \mathrm{C}$. All data shown are means $( \pm$ s.d.) from two or three experiments performed in triplicate. was dosedependent. As illustrated in Figure 1c, IGR39 cells attached to immobilised proteins from venom and to fibrinogen with similar efficiencies. The effect of venom likely implicated the integrin family, as no inhibition was observed when using an integrin-independent substratum, such as poly-L-lysine (Figure 1a). Moreover, the attachment of IGR39 cells to immobilised proteins from venom was dependent on $\mathrm{Ca}^{2+} / \mathrm{Mg}^{2+}$ and was increased by $\mathrm{Mn}^{2+}$, two typical properties of integrin-ligand interactions (Figure 1d).

\section{Purification and Characterisation of Lebectin}

In order to isolate the proteins acting on tumour cells adhesion, crude venom from $M$. lebetina was first fractionated by Sephadex G75 gel filtration chromatography (Figure 2a). Proteins from peak II, which contained most of the antiaggregating activity on platelets, were then subjected to cation exchange chromatography on a Mono S column (Figure 2b). Peak P2S appeared to be composed of a single protein, as separation by reverse-phase HPLC gave only one peak (Figure 2c). It is a protein with an isoelectric point of 7.8 (data not shown). The purity of this protein, designated as lebectin, was confirmed by SDS-PAGE. Lebectin has a molecular mass of $30 \mathrm{kDa}$ under nonreducing conditions and $16 \mathrm{kDa}$ under reducing conditions (Figure 2c, inset). Moreover, mass spectroscopy analysis revealed a molecular mass of $30468 \mathrm{Da}$ for native lebectin and $16158 \mathrm{Da}$ upon treatment with a reducing agent (data not shown). This suggested that lebectin is composed of two $16 \mathrm{kDa}$ subunits (either identical or with similar hydrophobicity) linked with disulphide bonds.

The $N$-terminal amino-acid sequence of the 39 first residues of lebectin confirmed that this protein is likely composed of two identical subunits and shows a relatively high degree of sequence identity with other known members of the CLP superfamily (Figure 3). The identity was higher with heterooligomeric CLPs, such as lebecetin, alboaggregin B, habu IX/X-bp or botrocetin, than with the homodimeric CLP LmsL.

\section{Lebectin Affects Adhesion of Tumour Cells}

Besides binding to platelet membrane proteins or blood coagulation factors, CLPs have recently demonstrated anti-integrin activity. ${ }^{6,9,10}$ In order to investigate the effect of lebectin on the behaviour of tumour cells, we first performed adhesion assays on a panel of purified ECM proteins by using various established human cell lines. As shown on Figure 4a, lebectin completely blocked the attachment of the melanoma cell line IGR39 to fibrinogen, fibronectin and laminin-1, while adhesion to vitronectin was only slightly decreased. 

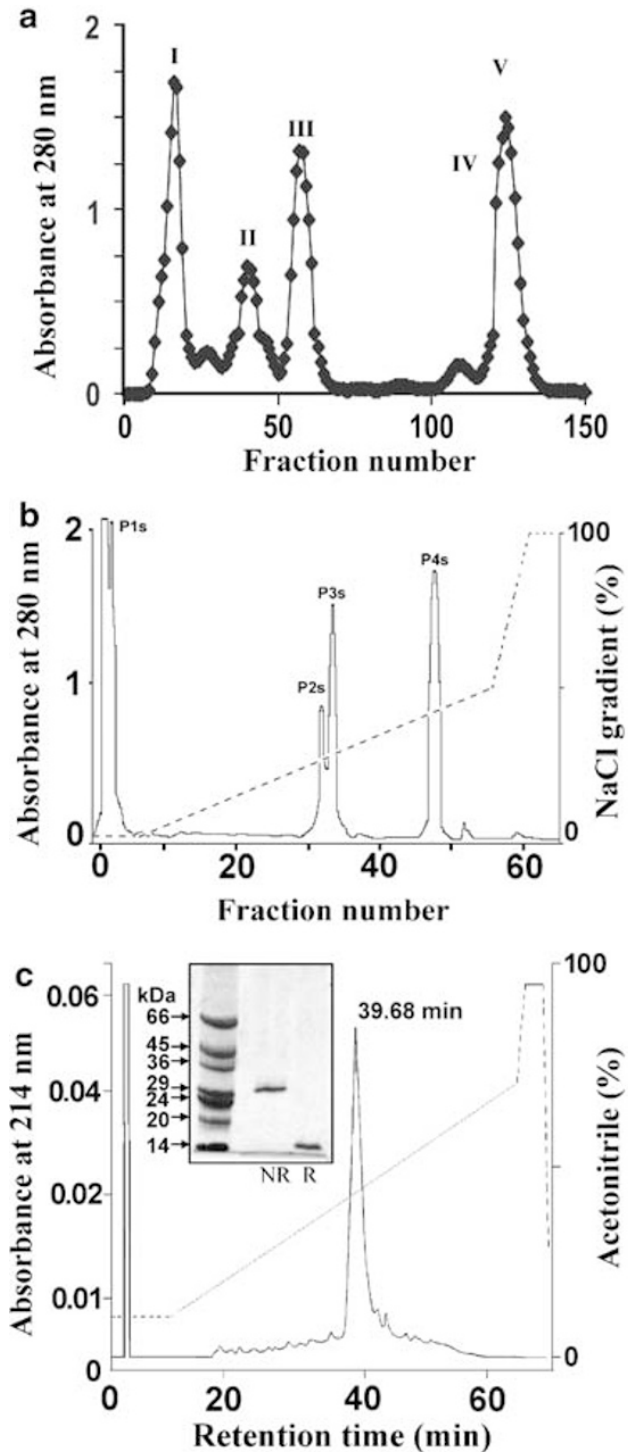

Figure 2 Purification and characterisation of lebectin. (a) Gel filtration chromatography of $M$. lebetina crude venom on a Sephadex G75 column. Elution was performed at $20 \mathrm{ml} / \mathrm{h}$ and $3 \mathrm{ml}$ aliquots were collected. (b) Cation exchange chromatography on a MonoS HR5/5 column using a FPLC system. Fractions from peak II of gel filtration were directly applied to the column equilibrated with $50 \mathrm{mM}$ HEPES $\mathrm{pH}$ 7.5. Elution was performed with a linear gradient of 0-1 M NaCl. (c) Proteins from peak P2S were resolved by RP-HPLC on a C8 column and eluted using an acetonitrile gradient. The inset shows purified lebectin analysed by SDS-PAGE under nonreducing (NR) and reducing (R) conditions.
The effect on attachment of K562 cells to fibronectin and IGR39 cells to fibrinogen (Figure 4b), fibronectin or laminin-1 (data not shown) was dosedependent. Lebectin also inhibited the adhesion of the fibrosarcoma cell line, HT1080 to fibrinogen and fibronectin (Figure 4c), but only partially affected that of the colonic HT29-D4 cells (Figure 4d). Whatever the cell line, lebectin did not affect the attachment to type I and IV collagens. Moreover, no inhibition could be observed with any cell line on the integrin-independent substratum, poly-L-lysine, suggesting that the effect of lebectin indeed involved the integrin family of adhesion receptors.

\section{Lebectin Abolishes Tumour Cells Migration and Invasion}

In order to colonise new organ sites, tumour cells have to access the lymphatic or blood vessel system, disseminate, extravasate and invade the new organ parenchyma. These events require cell adhesion, but also migration. We tested the ability of lebectin to inhibit integrin-dependent migration of HT1080 cells, using haptotaxis assays towards attractive proteins in modified Boyden chambers. As shown in Figure $525 \mu \mathrm{g} / \mathrm{ml}$ lebectin totally abolished HT1080 cells migration towards fibronectin (Figure $5 a$, upper panels). This inhibition was dosedependent with a partial effect at a concentration as low as $1 \mu \mathrm{g} / \mathrm{ml}$ (about $30 \mathrm{nM}$ ) (Figure 5b). Lebectin also affected migration of HT29-D4 and IGR39 cell lines (data not shown). However, as observed with cell adhesion, lebectin had not effect on migration of HT1080 cells towards type I collagen (Figure 5a, lower panels).

We next evaluated the effect of lebectin on tumour cell invasion using a previously described in vitro assay. ${ }^{20}$ Because HT1080 cells secrete large amounts of matrix metalloproteinases that rapidly hydrolyse fibrin gels, ${ }^{21}$ we therefore incorporated small amounts of collagen to perform invasion studies. As illustrated in Figure 6, lebectin at concentrations as low as $2 \mu \mathrm{g} / \mathrm{ml}(\sim 60 \mathrm{nM})$ completely blocked invasion of fibrin/collagen gels by HT1080 cells. In this assay, the venom peptide likely inhibited migration to fibrin, because invasion of collagen gels was unaffected (not shown).

\section{Lebectin \\ Lebecetin $\alpha$ chain \\ Habu IX/X-bp \\ Alboaggregin B \\ Botrocetin $\alpha$ chain \\ LmsL}

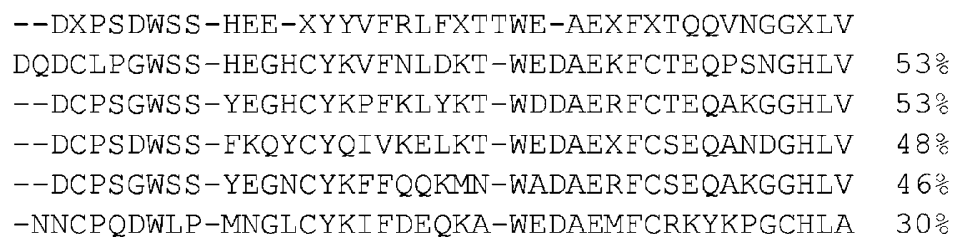

Figure 3 Comparison of the N-terminal amino-acid sequence of lebectin with those of others snake CLPs. Sequence homology was evaluated by computer search in the protein sequence database (BLAST search). Alignment of the N-terminal amino-acid sequence of lebectin with other CLPs from snake venom was performed with the program CLUSTAL X. The percentage of aminoacid identity with lebectin is indicated at the right side. 

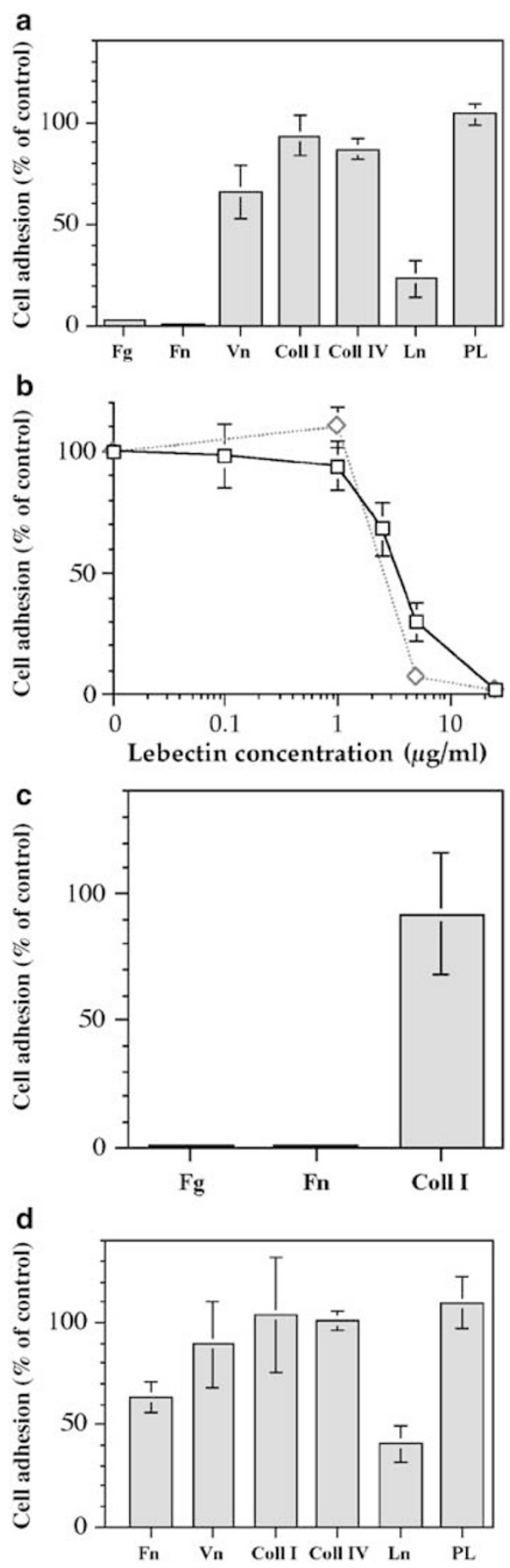

Figure 4 Lebectin inhibits the adhesion of various tumour cells. IGR39 (a), HT1080 (c) or HT29-D4 (d) cells were preincubated with $25 \mu \mathrm{g} / \mathrm{ml}$ lebectin for $30 \mathrm{~min}$ at room temperature. Cells were then added to 96-well microtiter plates coated with $10 \mu \mathrm{g} / \mathrm{ml}$ fibrinogen (Fg), fibronectin (Fn), vitronectin (Vn), type I or type IV collagens (Coll I and Coll IV, respectively) or poly-L-lysine (PL) or with $2 \mu \mathrm{g} / \mathrm{ml}$ laminin ( $\mathrm{Ln}$ ) and allowed to adhere for $1 \mathrm{~h}$ or $2 \mathrm{~h}$ at $37^{\circ} \mathrm{C}$. After washing, adherent cells were stained with crystal violet, solubilized by SDS and absorbance was measured at $600 \mathrm{~nm}$. (b) HT1080 (- $\square$-) or K562 (- $\diamond$-) cells were preincubated with the indicated concentrations of lebectin and allowed to adhere to microtiter plates coated with $10 \mu \mathrm{g} / \mathrm{ml}$ fibrinogen (HT1080 cells) or fibronectin (K562 cells). Data shown are means $( \pm$ s.d.) from two to four experiments performed in triplicate. They are expressed as a percentage of adhesion in the absence of lebectin. a

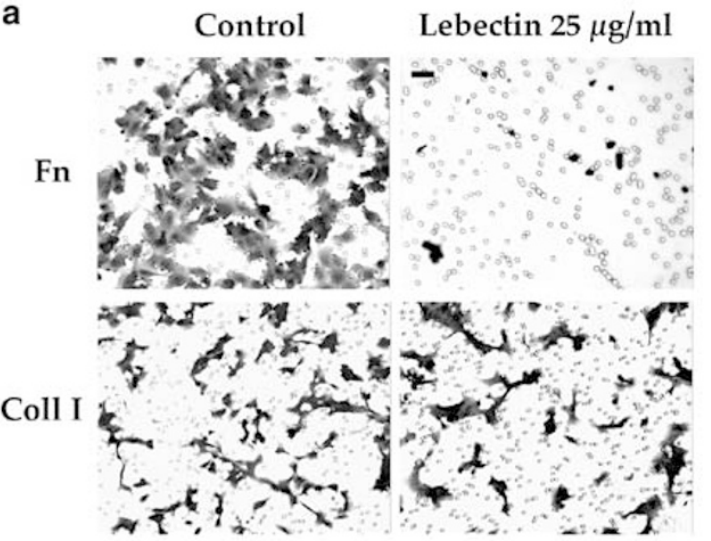

b

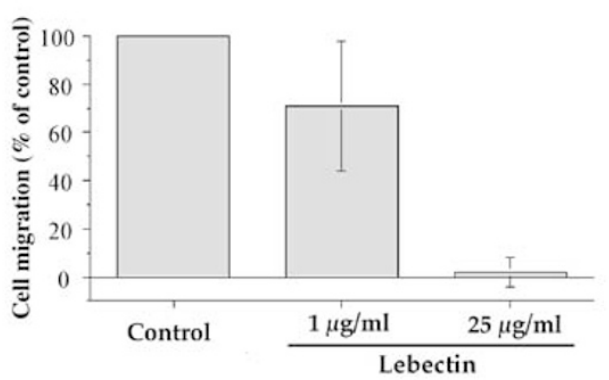

Figure 5 Lebectin inhibits migration of tumour cells. (a) Cell motility was determined in a modified Boyden chamber using porous membrane precoated with $10 \mu \mathrm{g} / \mathrm{ml}$ of fibronectin (Fn) or type I collagen (Coll I). After treatment with lebectin for $30 \mathrm{~min}$ at room temperature, HT1080 cells were seeded into the upper reservoir and allowed to migrate through the filter towards the lower reservoir for $5 \mathrm{~h}$ at $37^{\circ} \mathrm{C}$. Cells that migrated to the underside of the filter were stained with $0.1 \%$ crystal violet. Scale bar: $50 \mu \mathrm{m}$. (b) Cell migration towards fibronectin was performed upon lebectin treatment at the indicated concentration. After staining of cells with crystal violet, the colorant was solubilised with $1 \%$ SDS and absorbance was measured at $600 \mathrm{~nm}$. Data shown ( \pm s.d.) are from one experiment representative of three performed in triplicate.

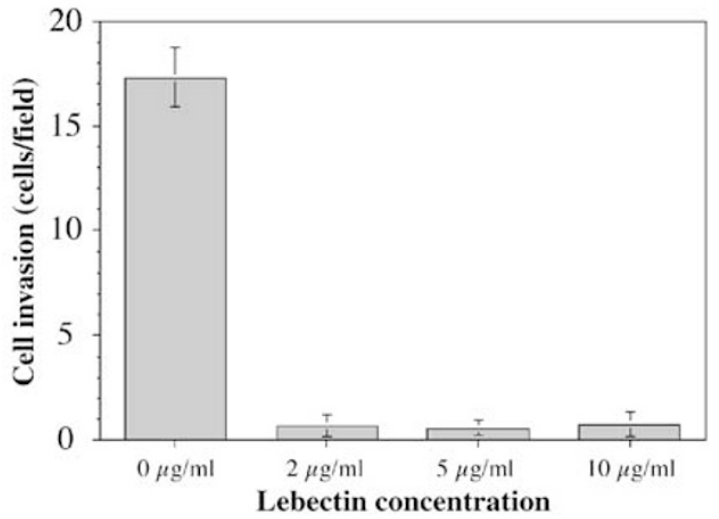

Figure 6 Lebectin inhibits invasion of fibrin gels. Subconfluent HT1080 cell monolayers in 24-well microtiter plate were covered with $200 \mu \mathrm{l}$ of a solution of DMEM/10\%FCS containing $5 \mathrm{mg} / \mathrm{ml}$ fibrinogen, $0.67 \mathrm{mg} / \mathrm{ml}$ type I collagen and lebectin at the indicated concentration. After fibrin polymerisation by adding $0.5 \mathrm{U} / \mathrm{ml}$ of thrombin, cells were allowed to invade the gel for $6 \mathrm{~h}$ at $37^{\circ} \mathrm{C}$. Invading cells that displayed a characteristic morphology were enumerated by microscopic observation. Data are means ( \pm s.d.) from two experiments performed in triplicate. 


\section{Lebectin Inhibits Proliferation of Tumour Cells}

It has long been known that most cell types require attachment to a substrate to be able to grow. As integrins are primarily responsible for cell adhesion to ECM, it is not surprising that they are involved in cell proliferation, ${ }^{22,23}$ In order to know whether lebectin interferes with proliferation, we first followed the growth of IGR39, HT1080 and K562 cells in the absence or in the presence of the peptide. For all cell lines, the number of cells in the wells was dramatically reduced by the presence of $10 \mu \mathrm{g} / \mathrm{ml}$ $(\sim 0.3 \mu \mathrm{M})$ lebectin in culture medium (Figure 7a). To confirm that the reduced cell number was really due to growth inhibition, HT1080 cells were cultured with lebectin for $18 \mathrm{~h}$ and proliferation was then visualised by detecting cells that have incorporated BrdU into DNA. As shown in Figure 7b, few nuclei exhibited uptake of BrdU in lebectintreated cells when compared to control condition. Thus, lebectin clearly affected DNA synthesis and appears to be a potent inhibitor of tumour cell proliferation.

\section{Discussion}

The snake venom proteins are well-known modulators of platelet adhesion receptors and their ligands (reviewed in [Andrews and Berndt, ${ }^{8}$ Brand et $\left.a l^{24}\right]$ ). Since their characterisation, snake disintegrins have been extensively studied. They specifically antagonise the integrin receptors and can thus prevent invasion of breast cancer cells and in vivo tumour progression. ${ }^{25}$ On the other hand, very little is known about the effect of venom CLPs on tumour cells behaviour. Here, we report the structural and biochemical characterisation of a new peptide, termed lebectin, isolated from the venom of the North Africa viper M. lebetina. Lebectin demonstrated a potent anti-integrin activity on various cancer cells.

Several lines of evidence suggest that lebectin is a member of the C-type lectins family. First, lebectin is composed of two $16 \mathrm{kDa}$ subunits, a structure found in C-type lectins from snake venom. ${ }^{26-28}$ Second, lebectin was recognised (in enzyme-linked immunosorbent assay (ELISA), Western blot and immunoprecipitation assays) by an antibody raised against lebecetin, an already characterised C-type lectin from $M$. lebetina venom. ${ }^{15,16}$ This suggests that, although lebecetin is an heterodimeric C-type lectin while lebectin is homodimeric, both proteins share some structural features. Third, the N-terminal amino-acid sequence shows a relatively high degree of sequence identity with other known members of the CLP superfamily. Curiously enough, the identity was higher with heterooligomeric CLPs such as lebecetin, alboaggregin B, habu IX/X-bp or botrocetin, ${ }^{15,29-31}$ than with the homodimeric CLP LmsL. ${ }^{26}$ Determination of the entire amino-acid sequence of lebectin is in progress in order to confirm its homodimeric structure.

Until recently, the anti-integrin activity among snake venom proteins was considered to be characteristic for disintegrins. However, it has been reported that EMS16, a CLP from E. multisquamatus inhibits endothelial cells migration by interacting with $\alpha 2 \beta 1$ integrin. ${ }^{6}$ Here, we extend this initial observation to various established human tumour cells from diverse origin and to other integrin-
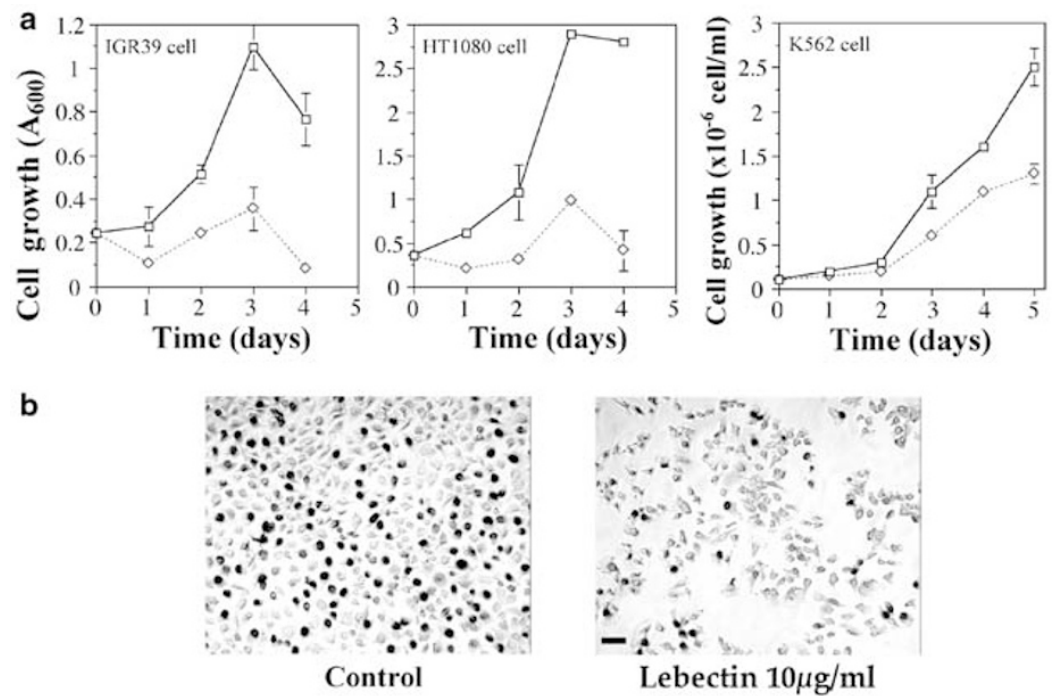

Figure 7 Lebectin inhibits tumour cells proliferation. (a) IGR39, HT1080 and K562 cells were cultured for the indicated periods of time in the absence (- $\square$-) or in the presence $(-\diamond-)$ of $10 \mu \mathrm{g} / \mathrm{ml}$ lebectin. IGR39 and HT1080 cells were quantified by staining with $0.1 \%$ crystal violet, solubilisation with $1 \%$ SDS and measure of absorbance at $600 \mathrm{~nm}$. K562 cells were enumerated by manual counting. The results ( \pm s.d.) are from a representative experiment of two performed in triplicate. (b) HT1080 cells were cultured in the presence or in the absence of lebectin for $18 \mathrm{~h}$ at $37^{\circ} \mathrm{C}$ and then with $10 \mu \mathrm{M}$ BrdU for an additional $2 \mathrm{~h}$ period. Cells that have incorporated BrdU into DNA (dark nuclei) were detected as described in Materials and methods. Scale bar: $100 \mu \mathrm{m}$. 
dependent functions. Lebectin inhibits adhesion of melanoma, fibrosarcoma, adenocarcinoma and leukaemia cells to different integrin ligands. Moreover, cell attachment to immobilised lebectin is enhanced by $\mathrm{Mn}^{2+}$ and is divalent cationdependent (not shown), two typical properties of integrins, suggesting that lebectin affects cell adhesion by interacting with ECM receptors of the integrin family.

Cell migration requires the formation of new attachments at the leading edge and the release of attachments at trailing edge of the cell..$^{32}$ Although the detailed mechanisms are not yet understood, it is clear that dynamic and reciprocal interactions between cell adhesion molecules, ECM and soluble factors are essential. ${ }^{5,33,34}$ Consequently, as primary receptors for ECM proteins, integrins are required for cell motility. Integrins also play a major role in cell invasion along with others protagonists, such as cadherins, matrix metalloproteinases or growth factors. ${ }^{35}$ The inhibitory effect of lebectin on cell migration and invasion is likely due to the reduced attachment to ECM proteins observed in the presence of the CLP. Indeed, both cell adhesion and migration are inhibited by lebectin in the case of fibronectin, whereas neither attachment nor migration to type I collagen are affected. In the same way, lebectin blocks adhesion to fibrinogen and invasion of three-dimensional matrices of fibrin, which derives from fibrinogen, but do not prevent invasion of collagen gels.

Lebectin also drastically decreases growth of melanoma, fibrosarcoma and leukaemia cell lines. Such an inhibition of tumour and endothelial cell growth has been reported for BJcuL, a CLP from the snake Bothrops jararacussu, ${ }^{36,37}$ although this inhibition by BJcuL required higher concentrations. Because lebectin impairs cell adhesion, its anti proliferative effect might be an indirect one, as detachment of adherent cells may cause apoptosis. This is probably not the case for several reasons. First, in the proliferation test, cells are seeded in standard culture conditions. ECM proteins are those brought by FCS, that is, mainly vitronectin and fibronectin. As illustrated in Figure 4, adhesion to vitronectin is barely affected by lebectin. Moreover, cells did not detach from the substrate during the test and no cell debris could be observed. Furthermore, if the effect of lebectin on proliferation was due to cell detachment, the ratio of stained vs unstained nuclei should have been the same in the presence and in the absence of lebectin. This is clearly not the case, as shown in Figure 7b. Finally, the detachment cannot be taken into account in the case of K562 cells because these leukemia cells grow in suspension. The antiproliferative effect of lebectin is thus likely due to the impediment of integrin function, as reported in the case of functionblocking anti-integrin antibodies. ${ }^{23}$ However, whether the effect on integrins is direct (eg, physical association) or indirect (via a third partner) remains to be determined.
Recent reports have shown that CLPs may interact with the platelet integrin $\alpha 2 \beta 11^{6,9,10}$ However, the effect of CLPs on integrin function might not be as simple as suggested by initial observations. Thus, aggretin and trimucytin were first described as activating platelets by binding to $\alpha 2 \beta 1$ integrin, ${ }^{11,12,38,39}$ but there is now evidence to suggest that these CLPs do not bind to $\alpha 2 \beta 1$ integrin. ${ }^{13,14,40}$ The fact that cell adhesion to collagens, which involves $\alpha 2 \beta 1$ integrins, is not affected by lebectin indicates that this integrin is probably not the target of lebectin. In addition, lebectin has not effect on migration towards type I collagen, a ligand of $\alpha 2 \beta 1$ integrin in HT1080 cells. ${ }^{41}$ The $\alpha 2 \beta 1$ integrin is likely not the only target of CLPs. It is possible that lebectin might act on several integrins because various different integrins mediate the adhesion of the tumour cells used in this study to fibrinogen, fibronectin and laminin-1. The integrin $\alpha 5 \beta 1$ may likely be involved, at least in some of the effects, because lebectin inhibited the adhesion and growth of the leukemia cell line K562 that only expresses this integrin at its cell surface. ${ }^{42}$ Moreover, the integrin $\alpha 5 \beta 1$ is expressed by both IGR39 and HT1080 cells. ${ }^{41}$ It is also worth pointing out, that HT29-D4 cells, that do not express $\alpha 5 \beta 1$ integrin, ${ }^{18,43}$ are very little sensitive to lebectin. The identification of the specific integrin(s) involved in the effects of lebectin on tumour cells behaviour is currently under investigation.

In conclusion, we have isolated and characterised a novel homodimeric C-type lectin protein with a potent anti-integrin activity. Indeed, this venomderived protein is able to prevent adhesion, migration, invasion and proliferation of tumour cells using in vitro assays. It could thus be interesting to check the effect of lebectin on in vivo tumorigenesis and metastasis development in animal models such as nude mouse or new born immunosuppressed rat.

\section{Acknowledgements}

We thank Professor Koussay Dellagi (Institut Pasteur de Tunis) for his continuous interest in this study and for his support. Dr Benlasfar Zakaria and Ben Zakour Lotfi (laboratoire vétérinaire, Institut Pasteur de Tunis) are acknowledged for providing viper venom. This work was supported in part by a grant from the CMCU (Comité Mixte de Coopération Universitaire France-Tunisie), the ARC (Association pour la Recherche sur le Cancer), the GEFLUC (Groupement des Entreprises Françaises dans la Lutte contre le Cancer) and the Ligue Nationale contre le Cancer.

\section{References}

1 Humphries MJ. Integrin structure. Biochem Soc Trans 2000;28:311-339. 
2 Small JV, Kaverina I, Krylyshkina O, et al. Cytoskeleton cross-talk during cell motility. FEBS Lett 1999;452: 96-99.

3 Geiger B, Bershadsky A, Pankov R, et al. Transmembrane crosstalk between the extracellular matrixcytoskeleton crosstalk. Nat Rev Mol Cell Biol 2001; 2:793-805.

4 Parise LV, Lee J, Juliano RL. New aspects of integrin signaling in cancer. Semin Cancer Biol 2000;10: 407-414.

5 Hood J, Cheresh D. Role of integrins in cell invasion and migration. Nat Rev Cancer 2002;2: 91-100.

6 Marcinkiewicz C, Lobb RR, Marcinkiewicz MM, et al. Isolation and characterization of EMS16, a C-lectin type protein from Echis multisquamatus venom, a potent and selective inhibitor of the $\alpha 2 \beta 1$ integrin. Biochemistry 2000;39:9859-9867.

7 Wang R, Kong C, Kolatkar P, et al. A novel dimer of a C-type lectin-like heterodimer from the venom of Calloselasma rhodostoma (Malayan pit viper). FEBS Lett 2001;508:447-453.

8 Andrews RK, Berndt MC. Snake venom modulators of platelet adhesion receptors and their ligands. Toxicon 2000;38:775-791.

9 Du XY, Navdaev A, Clemetson JM, et al. Bilinexin, a snake C-type lectin from Agkistrodon bilineatus venom agglutinates platelets via GPIb and $\alpha 2 \beta 1$. Thromb Haemost 2001;86:1277-1283.

10 Suzuki-Inoue K, Ozaki Y, Kainoh M, et al. Rhodocytin induces platelet aggregation by interacting with glycoprotein Ia/IIa (GPIa/IIa, Integrin $\alpha 2 \beta 1$ ). Involvement of GPIa/IIa-associated src and protein tyrosine phosphorylation. J Biol Chem 2001;276:1643-1652.

11 Navdaev A, Clemetson JM, Polgar J, et al. Aggretin, a heterodimeric C-type lectin from Calloselasma rhodostoma (malayan pit viper), stimulates platelets by binding to $\alpha 2 \beta 1$ integrin and glycoprotein $\mathrm{Ib}$, activating Syk and phospholipase $\mathrm{C} \gamma 2$, but does not involve the glycoprotein VI/FC receptor $\gamma$ chain collagen receptor. J Biol Chem 2001;276:20882-20889.

12 Chung CH, Peng HC, Huang TF. Aggretin, a C-type lectin protein, induces platelet aggregation via integrin $\alpha 2 \beta 1$ and GPIb in a phosphatidylinositol 3-kinase independent pathway. Biochem Biophys Res Commun 2001;285:689-695.

13 Bergmeier W, Bouvard D, Eble JA, et al. Rhodocytin (aggretin) activates platelets lacking $\alpha 2 \beta 1$ integrin, glycoprotein VI, and the ligand-binding domain of glycoprotein Ib $\alpha$. J Biol Chem 2001;276: 25121-25126.

14 Eble JA, Beermann B, Hinz HJ, et al. $2 \beta 1$ integrin is not recognized by rhodocytin but is the specific, high affinity target of rhodocetin, an RGD-independent disintegrin and potent inhibitor of cell adhesion to collagen. J Biol Chem 2001;276:12274-12284.

15 Sarray S, Srairi N, Hatmi M, et al. Lebecetin, a potent antiplatelet C-type lectin from $M$. lebetina venom. Biochim Biophys Acta 2003;1651:30-40.

16 Sarray S, Srairi N, Luis J, et al. Lebecetin, a C-lectin protein from the venom of $M$. lebetina that inhibits platelet aggregation and adhesion of cancerous cells. Haemostasis 2001;31:173-176.

17 Yatogho $\mathrm{T}$, Izumi $\mathrm{M}$, Kashiwagi $\mathrm{H}$, et al. Novel purification of vitronectin from human plasma by heparin affinity chromatography. Cell Struct Funct 1988;13:281-292.
18 Rigot V, Lehmann M, André F, et al. Integrin ligation and PKC activation are required for migration of colon carcinoma cells. J Cell Sci 1998;111:3119-3127.

19 Kadi A, Pichard V, Lehmann M, et al. Effect of microtubule disruption on cell adhesion and spreading. Biochem Biophys Res Comm 1998;246:690-695.

20 Naito M, Nomura H, Iguchi A. Migration of cultured vascular smooth muscle cells into non-crosslinked fibrin gels. Thromb Res 1996;84:129-136.

21 Jones PA, Laug WE, Benedict WF. Fibrinolytic activity in a human fibrosarcoma cell line and evidence for the induction of plasminogen activator secretion during tumor formation. Cell 1975;6:245-252.

22 Howe A, Aplin AE, Alahari SK, et al. Integrin signaling and cell growth control. Curr Opin Cell Biol 1998;10:220-231.

23 Cruet-Hennequart S, Maubant S, Luis J, et al. $\alpha \mathrm{v}$ integrins regulate cell proliferation through integrinlinked kinase (ILK) in ovarian cancer cells. Oncogene 2003;22:1688-1702.

24 Braud S, Bon C, Wisner A. Snake venom proteins acting on hemostasis. Biochimie 2000;82:851-859.

25 Zhou Q, Sherwin RP, Parrish C, et al. Contortrostatin, a dimeric disintegrin from Agkistrodon contortrix contortrix, inhibits breast cancer progression. Breast Cancer Res Treat 2000;61:249-260.

26 Aragon-Ortiz F, Mentele R, Auerswald EA. Amino acid sequence of a lectin-like protein from Lachesis muta stenophyrs venom. Toxicon 1996;34:763-769.

27 Hirabayashi J, Kusunoki T, Kasai K. Complete primary structure of a galactose-specific lectin from the venom of the rattlesnake Crotalus atrox. Homologies with $\mathrm{Ca}^{2+}$-dependent-type lectins. J Biol Chem 1991;266: 2320-2326.

28 de Carvalho DD, Marangoni S, Novello JC. Primary structure characterization of Bothrops jararacussu snake venom lectin. J Protein Chem 2002;21:43-50.

29 Kowalska MA, Tan L, Holt JC, et al. Alboaggregins A and B. Structure and interaction with human platelets. Thromb Haemost 1998;79:609-613.

30 Atoda $\mathrm{H}$, Ishikawa $\mathrm{M}$, Yoshihara $\mathrm{E}$, et al. Blood coagulation factor IX-binding protein from the venom of Trimeresurus flavoviridis: purification and characterization. J Biochem (Tokyo) 1995;118:965-973.

31 Usami Y, Fujimura Y, Suzuki M, et al. Primary structure of two-chain botrocetin, a von Willebrand factor modulator purified from the venom of Bothrops jararaca. Proc Natl Acad Sci USA 1993;90: 928-932.

32 Holly SP, Larson MK, Parise LV. Multiple roles of integrins in cell motility. Exp Cell Res 2000;261:69-74.

33 André F, Rigot V, Remacle-Bonnet M, et al. Protein kinases $\mathrm{C}-\gamma$ and $-\delta$ are involved in insulin-like growth factor I-induced migration of colonic epithelial cells. Gastroenterology 1999;116:64-77.

34 André F, Rigot V, Thimonier J, et al. Integrins and Ecadherin cooperate with IGF-I to induce migration of epithelial colonic cells. Int J Cancer 1999;83:497-505.

35 Quaranta V, Giannelli G. Cancer invasion: watch your neighbourhood!. Tumori 2003;89:343-348.

36 de Carvalho DD, Schmitmeier S, Novello JC, et al. Effect of BJcuL (a lectin from the venom of the snake Bothrops jararacussu) on adhesion and growth of tumor and endothelial cells. Toxicon 2001;39: 1471-1476.

37 Pereira-Bittencourt M, Carvalho DD, Gagliardi AR, et al. The effect of a lectin from the venom of the 
snake, Bothrops jararacussu, on tumor cell proliferation. Anticancer Res 1999;19:4023-4025.

38 Teng CM, Ko FN, Tsai IH, et al. Trimucytin: a collagenlike aggregating inducer isolated from Trimeresurus mucrosquamatus snake venom. Thromb Haemost 1993;69:286-292.

39 Huang TF, Liu CZ, Yang SH. Aggretin, a novel plateletaggregation inducer from snake (Calloselasma rhodostoma) venom, activates phospholipase $\mathrm{C}$ by acting as a glycoprotein Ia/IIa agonist. Biochem J 1995;309: 1021-1027.

40 Hers I, Berlanga O, Tiekstra MJ, et al. Evidence against a direct role of the integrin $\alpha 2 \beta 1$ in collagen-induced tyrosine phosphorylation in human platelets. Eur Biochem 2000;267:2088-2097.

41 Cardarelli PM, Yamagata S, Taguchi I, et al. The collagen receptor alpha 2 beta 1, from MG-63 and HT1080 cells, interacts with a cyclic RGD peptide. J Biol Chem 1992;267:23159-23164.

42 Jarvinen M, Ylanne J, Virtanen I. The effect of differentiation inducers on the integrin expression of K562 erythroleukemia cells. Cell Biol Int 1993;17:399-407.

43 Stutzmann J, Bellissent-Waydelich A, Fontao L, et al. Adhesion complexes implicated in intestinal epithelial cell-matrix interactions. Microsc Res Tech 2000;51:179-190. 